\title{
Winslow, C. (2020). Radical Seattle: The General Strike of 1919. New York University Press.
}

\section{Review by Michelle Chen}

Since the Covid-19 pandemic pummeled the economy, millions of workers have been displaced, while others continue to work amid increasingly harsh, often hazardous working conditions. With Covid forcing millions to choose between a paycheck and their health, some labor activists have hoped for a wave of wildcat strikes, and in the wake of the election, perhaps even a 'general strike' if Trump refused to concede.

There have been sparks of resistance, including spontaneous protests and walkouts, led by exhausted workers demanding fair wages and minimal safety protections at work.

Yet despite sporadic strikes, we are not quite seeing a massive labor insurgency, much less a general strike - not least because of constraints of the law and the unwillingness of mainstream unions to prioritize mass action over election campaigns and member services. Still, in a year of unprecedented calamity, the political moment seems ripe for some kind of grassroots uprising, as several generations have passed since organized labor disrupted the economy on a mass scale.

In 1919, in the midst of an even worse flu pandemic, workers in Seattle shut down their city, and ran it for five days. In Radical Seattle: The General Strike of 1919, Cal Winslow depicts an event that embodied the radical imagination of the Pacific Northwest at a moment of revolution and global turmoil — a moment that may resonate with workers' anxiety and outrage today.

The country's first full-fledged general strike, Winslow writes, began as a campaign of solidarity with the city's shipyard workers, who were embroiled in a labor standoff over wages, but it also reflected the evolution of class formation in a multiethnic, cosmopolitan city with a libertarian streak.

Winslow lays out the history of Seattle in the years leading up to the strike - its origins in settler colonialism and the distinct identity it forged as a maritime city at the far-west edge of America's growing empire. By 1919, in the wake of World War I, the city's atmosphere was charged with currents of anger and violence unfolding across the country. Race riots and food riots had erupted in cities. The flu pandemic of 1919 had ravaged working-class communities. As workers were being slaughtered in the war - which Seattle's branch of the American Federation of Labor (AFL) had opposed - thousands of strikes erupted nationwide, and in Seattle, some were led by the militant Industrial Workers of the World (IWW). The Bolshevik revolution of 1917 inspired Seattle's radicals - a network of socialists and union organizers - to envision their city as the vanguard of the American labor movement.

Though the shipyard workers' campaign was mostly about fair wages, the call for a solidarity 
strike across the city represented a fundamental tension in the labor movement between the craft and industrial unions, as groups like the IWW believed in organizing 'one big union' across traditional occupational lines.

But in Seattle, the vision of organizing across occupational lines prevailed even among AFL members. Representing 110 local AFL-affiliates, the Central Labor Council, helmed by a Sunday school teacher and IWW sympathizer James Duncan, bucked the national leadership and championed a broad-based industrial rank-and-file movement, and by extension, sympathy strikes that symbolically and materially linked all workers' struggles.

The Russian Revolution also informed the culture of Seattle's labor movement. 'Seattle's workers saw peasants seizing land, soldiers marching away from the trenches, marching home,' Winslow writes. 'They saw people fighting for freedom and welcomed them.'

Tens of thousands of workers participated in the general strike, with a core of about 45,000 shipyard workers in Seattle and Tacoma, buttressed by unanimous or near-unanimous strike votes from the local unions, from miners to musicians. For a few days in February workers ruled the city.

The shutdown of the city's economy did not, as critics had speculated, trigger a social unraveling. In fact, the leaders of the strike strove to maintain social order after the local economy ground to a halt. Although 'the employers and the press clamored for blood,' Winslow writes, the strikers understood the potent symbolism of peace in a city whose inhabitants had been rocked by global and communal conflict: 'There was indeed virtually no violence, and that is what the strikers wanted, which is perplexing only if radicalism is associated with violence.'

The leaders of the strike also took pains to maintain vital public services: the welfare committee managed basic sanitation, ensuring that garbage pick-up continued under a designated trash collection crew; they kept firefighters on the job; established the 'Labor Guards,' comprised of union officers and veterans, to carry out public-safety patrols; and maintained critical infrastructure like telephone wires and electricity supply. While a hush settled over the streets, workers' lives continued in an autonomous collective social sphere. Union members ran 'strike kitchens' that ensured no one in the city went hungry, churning out tens of thousands of meals, with the help of hundreds of volunteers. Women workers, such as the hotel maids and laundry workers, mobilized and volunteered alongside the men.

The spirit of solidarity even managed to puncture the city's deep racial divides, as the strike was embraced by the city's Japanese immigrant workers, who were at that time besieged by growing anti-Asian hostility across the West.

And then, almost as suddenly as it had emerged, the strike evaporated. It did not end with a federal crackdown, as later strikes would; nor did it collapse from internecine conflict, as opponents probably hoped it would. According to Winslow, the general strike dissolved amid a combination of media attacks, threats of martial law from the mayor, and intervention from AFL higher-ups who were alarmed at Seattle CLC's going rogue. 
Winslow's conclusion on what to make of the strike seems deliberately vague. Primarily his work is a counterpoint to the media narrative that the strike was somehow a 'failure'; he sees the strike as an unprecedented act of working-class unity and grassroots democracy. Although detractors on the left and the right have sought to 'belittle' and 'discredit' the movement as too extreme or 'naive,' he argues, 'the General Strike represented the highest point in a longer process of socialist and working-class organization.' At the same time, neither was the general strike all that revolutionary. The principal agitators had sought to push the edges of what was possible for an industrial action. Even in radical Seattle, the general strike was always a bit of a Rorschach test for distinct communities who participated with varying degrees of pragmatism and idealism. 'It wasn't that the strikers were inexperienced as organizers and fighters,' Winslow surmises. 'Rather, there had never been such a strike before, not in the United States, and their aims were not always clear. Some were striking to gain a definite wage increase for their brother workers in the shipyards. Others, a very few, were striking because they thought 'The Revolution' was about to arrive.' Many saw the strike 'just as a show of solidarity.'

So Winslow's history of the strike concludes a bit like the event itself: without any great climax, just an appreciation of the power of a direct action that succeeded primarily in demonstrating what workers could achieve in an American city: even if the worker's core demands were basic, the tactics - seizing the local economy and governing themselves-encapsulated a visionary ethos. Over one hundred years later, Seattle's general strike is a reminder that the sheer audacity of a whole city walking off the job, even if just for a few days, is enough to scare hell out of the powers that be-not because it threatens chaos, but because, when workers are in control, a true labor peace can emerge.

\section{Reviewer Bio}

Michelle Chen teaches at the City University of New York, is a contributing editor at Dissent Magazine, and co-hosts the Belabored podcast. 